\title{
T-Cell Lymphopenia Detected by Newborn Screening in Two Siblings with an Xq13.1 Duplication
}

\author{
Xavier Rios, Ivan K. Chinn, Jordan S. Orange, Celine I. Hanson and Nicholas L. Rider* \\ Center for Human Immunobiology, Baylor College of Medicine, Texas Children's Hospital, Houston, TX, United States
}

Newborn screening for severe combined immunodeficiency has proven successful in identifying infants with T-cell deficiencies before they become severely ill. Additionally, the newborn screen can detect subtle early phenotypes that may become severe later in life. We present the case of siblings with features suggestive of T-cell lymphopenia identified as having low T-cell receptor excision circles counts by newborn screening. Expanded immune testing showed robust lymphocyte mitogen and antigen responses with normal vaccine responses and immunoglobulin levels for both boys over time. Genetic analysis revealed an Xq13.1 duplication in each child not found in the mother. The variant is downstream of the IL2RG gene with potential regulatory significance, suggesting a mechanism for the T-cell lymphopenia. The newborn screen provided these patients

OPEN ACCESS

Edited by: Rosa Bacchetta, Stanford University, United States

Reviewed by: Andrew Gennery, Newcastle University, United Kingdom Antonio Condino-Neto, University of São Paulo, Brazil

${ }^{*}$ Correspondence: Nicholas L. Rider nlrider@bcm.edu

Specialty section: This article was submitted to Pediatric Immunology, a section of the journal

Frontiers in Pediatrics

Received: 27 October 2016 Accepted: 27 June 2017

Published: 18 July 2017

Citation:

Rios X, Chinn IK, Orange JS, Hanson Cl and Rider NL (2017) T-Cell Lymphopenia Detected by Newborn

Screening in Two Siblings with an Xq13.1 Duplication.

Front. Pediatr. 5:156. doi: 10.3389/fped.2017.00156 heightened surveillance and patient-specific management, including delayed live vaccines and Pneumocystis jiroveci pneumonia prophylaxis. Fortunately, the brothers have not suffered invasive or opportunistic infections and are well at ages 3 and 4 years. In this report, we illustrate the challenges of managing seemingly asymptomatic immunodeficient patients without a definitive genetic diagnosis and show how unbiased genetic analysis can expand understanding about primary immunodeficiency phenotypes.

Keywords: severe combined immunodeficiency, lymphopenia, T-cell receptor excision circles, primary immunodeficiency, idiopathic T-cell lymphopenia, Xq13.1

\section{INTRODUCTION}

The newborn screen T-cell receptor excision circles (TRECs) assay successfully identifies patients with significant T-cell lymphopenia before they become severely ill. As a marker for recent thymic emigrants, low numbers of TRECs serve as a proxy for T-cell lymphopenia, a key characteristic of many primary immunodeficiencies, including severe combined immunodeficiency (SCID) (1). However, the sensitivity of the TREC screen allows for detection of milder T-cell deficiency phenotypes as well. These immunodeficiencies have variability in age of onset, clinical manifestations, and immunological parameters (2). One of these intermediate phenotypes is "leaky" SCID, defined by low T-cell counts $(300-1,500$ cells $/ \mu \mathrm{L})$ and reduced proliferation to mitogens, most notably phytohemagglutinin. Idiopathic T-cell lymphopenia might represent a milder form of a SCID phenotype spectrum, with low T-cell counts but normal proliferation to mitogens (3). For example, mutations in the RAG1 gene can cause a broad range of immunodeficiency presentations $(4,5)$, including a case of idiopathic T-cell lymphopenia seen in a 5-year-old girl with varicella pneumonia (6). Therefore, idiopathic T-cell lymphopenia might be caused by milder genetic defects in SCID-causing genes.

\section{Cases}

Patient 1 was a male born at 37 weeks of gestational age to an African-American mother with gestational diabetes controlled by insulin. He underwent evaluation at 7 weeks of age after his newborn 
screens from birth and 2 weeks revealed TREC of 80 and 0 copies/ $\mathrm{mL}$, respectively. There was no family history of early infant deaths or consanguinity. Clinical findings were notable for mild facial dysmorphism, low set ears, and transverse phalangeal creases. The immunologic evaluation revealed $\mathrm{T}$-cell subset abnormalities: decreased $\mathrm{CD}^{+}$and $\mathrm{CD}^{+}$cell counts with conserved CD4:CD8 ratio and elevated $\mathrm{CD} 20^{+}$and $\mathrm{HLA}-\mathrm{DR}^{+}$cells (Table 1). Otherwise, he had normal immunoglobulin levels, normal NK cell counts, normal lymphocyte proliferation to antigens and mitogens, and appropriate antibody responses to diphtheria, tetanus, and conjugated Streptococcus pneumoniae vaccination. Live vaccines were delayed initially until repeat testing showed adequate lymphocyte

TABLE 1 | Immunologic laboratory values for siblings with idiopathic T-cell lymphopenia.

\begin{tabular}{|c|c|c|}
\hline Lab value (units) & Patient 1 & Patient 2 \\
\hline $\operatorname{lgG}(\mathrm{mg} / \mathrm{dL})$ & $514(207-904)$ & $597(207-904)$ \\
\hline $\lg \mathrm{A}(\mathrm{mg} / \mathrm{dL})$ & $15(10-45)$ & $29(10-50)$ \\
\hline $\operatorname{lgM}(\mathrm{mg} / \mathrm{dL})$ & $40(15-96)$ & $52(18-80)$ \\
\hline $\operatorname{lgE}(\mathrm{IU} / \mathrm{mL})$ & $5.6(1.5-52.3)$ & $11.4(1.5-52.3)$ \\
\hline Diphtheria toxin lgG antibody (IU/mL) & $6.4(>0.1)$ & ND \\
\hline Tetanus toxoid IgG antibody (IU/mL) & 0.8 & ND \\
\hline S. pneumoniae antibody Type 1 ( $\mu \mathrm{g} / \mathrm{mL})$ & $>33.02(>1)$ & ND \\
\hline S. pneumoniae antibody Type $3(\mu \mathrm{g} / \mathrm{mL})$ & $2.28(>1)$ & ND \\
\hline S. pneumoniae antibody Type 4 ( $\mu \mathrm{g} / \mathrm{mL})$ & $>11.97(>1)$ & ND \\
\hline S. pneumoniae antibody Type $5(\mu \mathrm{g} / \mathrm{mL})$ & $>42.77(>1)$ & ND \\
\hline S. pneumoniae antibody Type 6B ( $\mu \mathrm{g} / \mathrm{mL})$ & $3.21(>1)$ & ND \\
\hline S. pneumoniae antibody Type $7 \mathrm{~F}(\mu \mathrm{g} / \mathrm{mL})$ & $10.06(>1)$ & ND \\
\hline S. pneumoniae antibody Type 8 ( $\mu \mathrm{g} / \mathrm{mL})$ & $0.15(>1)$ & ND \\
\hline S. pneumoniae antibody Type 9N ( $\mu \mathrm{g} / \mathrm{mL})$ & $3.77(>1)$ & ND \\
\hline S. pneumoniae antibody Type 9V ( $\mu \mathrm{g} / \mathrm{mL})$ & $13.73(>1)$ & ND \\
\hline S. pneumoniae antibody Type $12 \mathrm{~F}(\mu \mathrm{g} / \mathrm{mL})$ & $0.26(>1)$ & ND \\
\hline S. pneumoniae antibody Type 14 ( $\mu \mathrm{g} / \mathrm{mL})$ & $13.58(>1)$ & ND \\
\hline S. pneumoniae antibody Type $18 \mathrm{C}(\mu \mathrm{g} / \mathrm{mL})$ & $>47.50(>1)$ & ND \\
\hline S. pneumoniae antibody Type 19F ( $\mu \mathrm{g} / \mathrm{mL})$ & $>59.27(>1)$ & ND \\
\hline S. pneumoniae antibody Type 23F ( $\mu \mathrm{g} / \mathrm{mL})$ & $>18.35(>1)$ & ND \\
\hline PHA 10 mg/mL (163,507-415,087cpm) & 275,728 & 101,120 \\
\hline 1.0 g/mL (35,494-225,107cpm) & 51,457 & 15,990 \\
\hline ConA 50 mg/mL (80,718-286,866cpm) & 207,275 & 38,039 \\
\hline 5.0 g/mL (28,998-108,585 cpm) & 84,863 & 33,107 \\
\hline PWM 100 ng/mL (37,006-157,955cpm) & 76,678 & 50,290 \\
\hline 10 ng/mL (24,369-94,311cpm) & 43,854 & 11,582 \\
\hline Unstimulated (215-1,161 cpm) & 445 & 236 \\
\hline Candida antigen (>2,000 cpm) & 10,267 & 18,283 \\
\hline Diphtheria antigen (>2,000 cpm) & 15,633 & 18,642 \\
\hline Tetanus antigen (>2,000 cpm) & 2,336 & 12,370 \\
\hline $\mathrm{CD}^{+}\left(1,920-4,99110^{3} \mathrm{cell} / \mathrm{UL}\right)$ & 1,382 & 2,101 \\
\hline $\mathrm{CD}^{+}{ }^{+} \mathrm{CD}^{+}+\left(1,546-3,67310^{3} \mathrm{cell} / \mathrm{UL}\right)$ & 1,092 & 1,447 \\
\hline $\mathrm{CD}^{+}{ }^{\mathrm{CD}} 8^{+}\left(359-1,48910^{3} \mathrm{cell} / \mathrm{UL}\right)$ & 276 & 600 \\
\hline $\mathrm{CD}{ }^{+}{ }^{+}\left(256-1,57910^{3} \mathrm{cell} / \mathrm{UL}\right)$ & 2,765 & 3,242 \\
\hline $\mathrm{CD}^{-}{ }^{-} \mathrm{CD}^{2} 6^{+} \mathrm{CD} 16^{+}\left(116-78310^{3} \mathrm{cell} / \mathrm{UL}\right)$ & 415 & 480 \\
\hline HLA-DR+ (59-457 10³ cell/UL) & 3,087 & 3,722 \\
\hline $\mathrm{CD}^{+}{ }^{+} \mathrm{HLA}^{-\mathrm{DR}^{+}}\left(0-25010^{3} \mathrm{cell} / \mathrm{UL}\right)$ & 92 & 180 \\
\hline $\mathrm{CD}^{20}+\left(59-45710^{3} \mathrm{cell} / \mathrm{UL}\right)$ & 2,949 & 3,302 \\
\hline $\mathrm{CD}^{+}\left(1,009-1,93610^{3} \mathrm{cell} / \mathrm{UL}\right)$ & 1,382 & 38 \\
\hline $\mathrm{CD} 6^{+}\left(137-47810^{3} \mathrm{cell} / \mathrm{UL}\right)$ & 323 & 360 \\
\hline CD8+CD56+ (30-200 10³ cell/UL) & 138 & 120 \\
\hline $\mathrm{CD}^{+}{ }^{+} \mathrm{CD} 45 \mathrm{RA}^{+}\left(134-96910^{3} \mathrm{cell} / \mathrm{UL}\right)$ & 783 & 1,141 \\
\hline $\mathrm{CD}^{+}{ }^{+} \mathrm{CD} 45 \mathrm{RO}^{+}$(301-919 103 cell/UL) & 230 & 360 \\
\hline $\mathrm{CD} 9^{+} \mathrm{CD} 27^{+}\left(19-13110^{3} \mathrm{cell} / \mathrm{UL}\right)$ & 23 & 30 \\
\hline HIV 1 DNA PCR & Not detected & ND \\
\hline
\end{tabular}

Age-appropriate normal ranges in parenthesis.

ND, not done. proliferation to antigens and mitogens. He tolerated varicella and measles, mumps, and rubella vaccines. At 17 months, his $\mathrm{CD}^{+} \mathrm{T}$-cell counts dropped below 300 cells/ $\mu \mathrm{L}$ (Figure 1), and he started Bactrim for Pneumocystis jiroveci pneumonia (PJP) prophylaxis.

Soon after birth, he became hypoxemic during feeds and a swallow study showed severe gastroesophageal reflux disease (GERD). The reflux likely led to failure to thrive with dysphagia and recurrent emesis that resolved at 23 months. He was hospitalized at 2 months of age to expedite workup for his positive TREC screen result. During this hospilatization, he developed a fever to $39.3 \mathrm{~F}$, with nasal washings PCR positive for rhinovirus and parainfluenza. Subsequently, he has suffered occasional upper respiratory infections, acute otitis media approximately two to four times per year, two episodes of hand, foot, and mouth disease, and two episodes of mild pneumonia treated as an outpatient. He has history of mild developmentally delayed, walking at 14 months and speaking 10-15 words at 24 months. Reportedly, the two older siblings and his Hispanic father have developmental delay and intellectual disability.

Patient 2 was a male born at 35 weeks and 6 days gestational age with a pregnancy complicated by gestational diabetes. His newborn screening also revealed very low TRECs. In the first weeks of life, he was hospitalized for hypoglycemia, likely from gestational diabetes and then bronchiolitis, recovering uneventfully. Other infectious complications included several episodes of otitis media, hand, foot, and mouth disease, and influenza; like

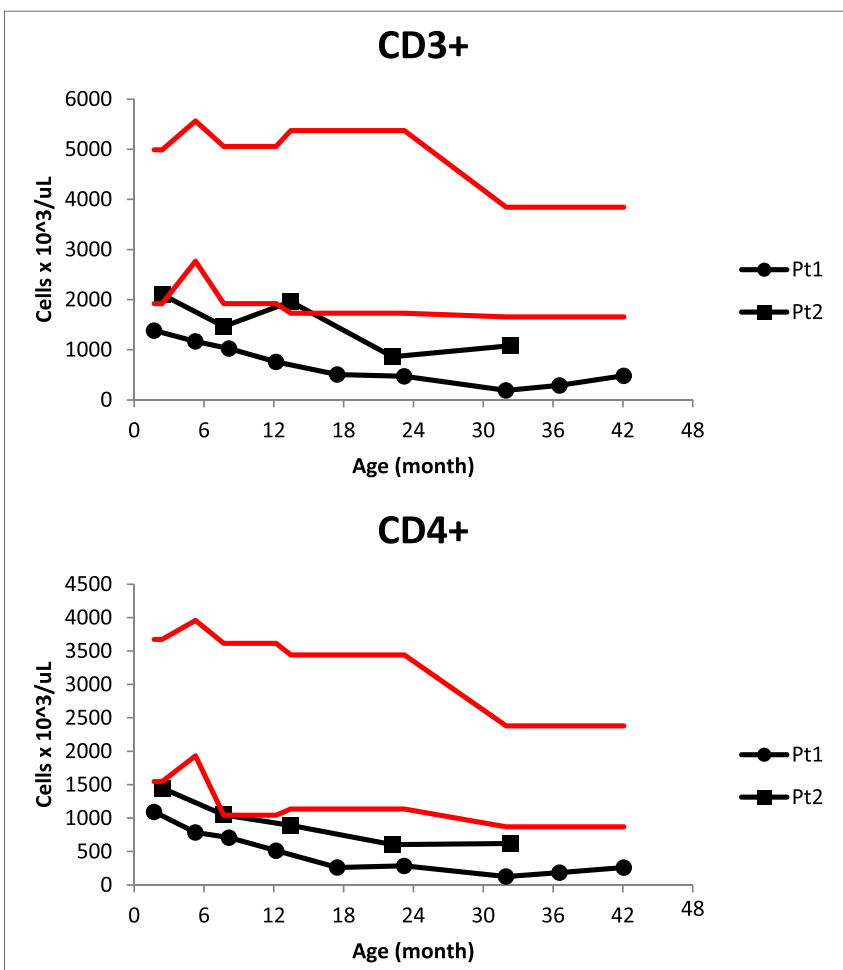

FIGURE $1 \mid \mathrm{CD}^{+}$and $\mathrm{CD}^{+}$cell counts in progressive lymphopenia of two siblings with low T-cell receptor excision circles on newborn screening. Red lines delimit the normal range for age. 
his brother, he recovered. Unlike his older brother, he did not have clinical GERD, failure to thrive, or developmental delay. His immunologic evaluation also revealed normal immunoglobulin levels, normal NK cell counts, normal lymphocyte responses to mitogens and antigens, and decreased T-cell counts, albeit less severe than his brother (Table 1; Figure 1).

\section{Genetic Analysis}

Genetic workup via chromosomal microarray revealed a 1-3 $\mathrm{kb}$ Xq13.1 duplication covering exons 25-28 of the MED12 gene. The duplication was present in both affected siblings, but absent in two healthy siblings and both parents (Figure 2). Identification of the Xq13.1 duplication was followed by whole exome sequencing of all family members. A list of the genetic variants that segregate only with the affected siblings is provided (Table 2). These variants are not in genes known to be involved in primary immunodeficiencies. Exome sequencing revealed that the two siblings inherited different $\mathrm{X}$ chromosomes from their mother, which argues against a maternal balanced translocation. Gonadal mosaicism may explain how the two siblings can have a duplication not seen in their parents, a mechanism reported in cases of Wiskott-Aldrich syndrome (7) and X-linked SCID $(8,9)$.

\section{Consent}

Informed consent for research studies for the patients and parents, including genetic testing, were obtained through BCM

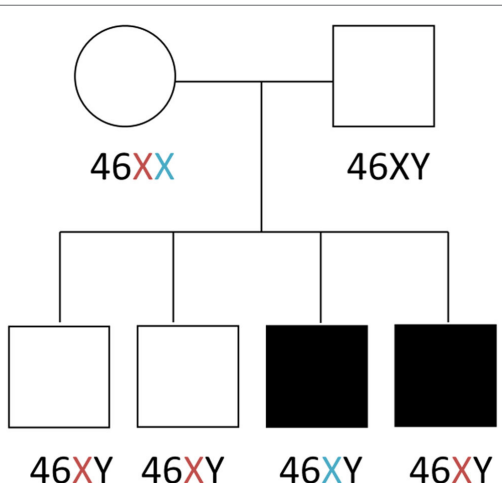

FIGURE 2 | Family pedigree.
Institutional Review Board approved protocols. Both parents provided informed consent for participation.

\section{BACKGROUND}

T-cell receptor excision circles screening identifies patients born with low T-cell counts. The test has been successful not only at detecting SCID but also other conditions such as idiopathic T-cell lymphopenia. The frequency of idiopathic T-cell lymphopenia detected by TRECs screening is estimated at 1 per 250,000 births (3). This condition is a diagnosis of exclusion and needs to be distinguished from other causes of newborn T-cell lymphopenia such as prematurity or neonatal illness. Longitudinal testing will show recovery of cell counts in those conditions, while idiopathic T-cell lymphopenia will remain with low T-cell counts. An analogous condition in adults, idiopathic $\mathrm{CD}^{+}$lymphocytopenia, was described in a prospective cohort study involving 39 patients who were diagnosed via an incidental laboratory finding or an unexplained opportunistic infection (10). Although it was termed CD $4^{+}$lymphopenia, about $40 \%$ of these patients had both low $\mathrm{CD}^{+}$and $\mathrm{CD}^{+}$cell counts, which was associated with higher risk of infections and mortality. A literature review of 259 reported idiopathic $\mathrm{CD} 4^{+}$lymphopenia cases found that at diagnosis the mean age was 40.7 years, $62 \%$ of cases were male, $87.6 \%$ had one or more opportunistic infection, $14.2 \%$ had an autoimmune disease, and $18.1 \%$ had a malignancy (11). Several T-cell abnormalities have been detected in patients with idiopathic $\mathrm{CD}^{+}$lymphopenia, including overexpression of Fas leading to increased apoptosis (12) and decreased surface expression of CXCR4 (13).

\section{DISCUSSION}

We report two brothers with low TREC levels and idiopathic T-cell lymphopenia. The T-cell lymphopenia in our patients has been persistent and progressive, arguing against secondary causes such as prematurity. Even though Patient 1 had a slightly sicker course during early infancy, this was likely due to his reflux and failure to thrive. They both have normal in vitro T-cell function and ability to combat viral infections, arguing against a "leaky" SCID diagnosis. In addition, both of them have an Xq13.1

TABLE 2 | Results of exome sequencing.

\begin{tabular}{|c|c|c|c|c|}
\hline Gene & Genomic coordinates & Zygosity & $\begin{array}{c}\text { ExAC allelic } \\
\text { frequency }\end{array}$ & Gene function \\
\hline CTAGE15P & chr7:143269281_A > C & Hom & 0 & Pseudogene, cutaneous T-cell lymphoma-associated antigen family \\
\hline TBC1D8B & chrX:106082584_T> G & Hom & 0.0006 & May act as a GTPase-activating protein for Rab family protein(s) \\
\hline NAP1L3 & chrX:92926826_T > C & Hom & 0.0006 & $\begin{array}{l}\text { Intron-less gene that encodes a member of the nucleosome assembly protein family. } \\
\text { Closely linked to a region of genes responsible for several X-linked mental retardation } \\
\text { syndromes }\end{array}$ \\
\hline PPARGC1B & chr5:149200068_G > A & Het & 0.00002 & $\begin{array}{l}\text { The protein encoded by this gene stimulates the activity of several transcription } \\
\text { factors and nuclear receptors, including estrogen receptor alpha, nuclear respiratory } \\
\text { factor } 1 \text {, and glucocorticoid receptor }\end{array}$ \\
\hline OR1S2 ${ }^{\mathrm{a}}$ & chr11:57970695_C > G & Het (maternal) & 0.00003 & Odorant receptor \\
\hline OR1S2 ${ }^{\mathrm{a}}$ & chr11:57971546_A > C & Het (paternal) & 0.003 & Odorant receptor \\
\hline
\end{tabular}

The six gene variants found only present in affected siblings and not unaffected family members.

${ }^{a}$ Compound heterozygous. 
$\operatorname{chrX}(\mathrm{q} 13.1) \quad$\begin{tabular}{|l|l|l|l|l|l|l|l|l|l|l|l|}
\hline \\
\hline
\end{tabular}

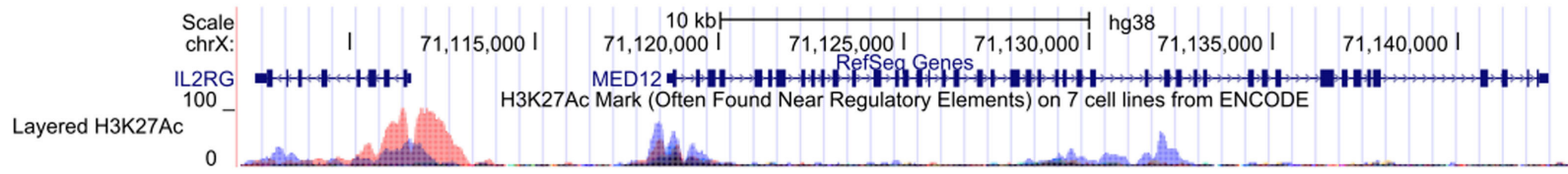

FIGURE 3 | Xq13.1 duplication region shared by affected siblings. The red box shows exons 25-28 of the MED12 gene, which were duplicated in the two affected patients with idiopathic T-cell lymphopenia. This region contains H3K2AC histone marks from the Encyclopedia of DNA Elements. UCSC Genome Browser GRCh38/hg38 assembly (16).

duplication region is downstream of the IL2RG gene, the causal gene of the most common form of SCID, X-linked SCID (14). Based on the Encyclopedia of DNA Elements data, this region might be of regulatory significance (Figure 3). It is tempting to hypothesize that copy number changes of this potential regulatory region could lead to dysregulation of the IL2RG gene and impaired homeostatic maintenance of T-cell levels. However, our patients have normal $\mathrm{NK}$ and $\mathrm{B}$ cell counts, which is not expected in X-linked SCID. One explanation for this could be pleiotropy of a mutation involving a regulatory region, leading to differential cell type phenotypes. Alternatively, the Xq13.1 duplication might have inserted in an immunologically relevant location, such as gene necessary for T-cell development or survival. Such a rearrangement could cause idiopathic T-cell lymphopenia, as has been previously reported in other cases $(6,15)$. Finally, Xq13.1 duplication could be an incidental finding unrelated to the T cell lymphopenia. Further studies are needed to further elucidate the genetic basis of our patient's phenotype.

One advantage of early T-cell lymphopenia detection was that heightened surveillance lead to patient-specific medical management. For example, live vaccines were delayed until longitudinal testing showed normal $\mathrm{T}$-cell responses to antigens and mitogens and appropriate responses to non-live vaccines. Furthermore, Patient 1 was started on PJP prophylaxis once his $\mathrm{CD}^{+}$cell counts dropped below 300 cells $/ \mu \mathrm{L}$, while Patient 2 has not required this. It is unclear why the older sibling has lower counts, although his initial failure to thrive might have contributed to it. Alternatively, their underlying genetic disorder might exhibit variable phenotypic penetrance.

The cases reported here illustrate the challenge of managing asymptomatic patients with idiopathic T-cell lymphopenia detected by the TREC screen. The non "full SCID" immunodeficiencies detected by the TREC assay have a variable age of onset, clinical manifestations, and immunological parameters. SCID and "leaky" SCID display reduced mitogen proliferation studies and significant susceptibility to infection, justifying bone marrow transplantation. In idiopathic T-cell lymphopenia, it is unclear if the immune function will remain normal or deteriorate over time. Longitudinal tracking of these patients will be essential for understanding their phenotype. It may be discovered that some of the patients diagnosed during infancy with idiopathic T-cell lymphopenia represent the earliest presentation of the idiopathic CD4-cell lymphopenia described in adults.
It is critical to know if our patients' defect is known or expected to worsen and evolve "leaky" SCID. A causal genetic diagnosis would be valuable because it can delineate a clinical course and pathway-specific management. However, whole exome sequencing did not detect any mutations in genes known to cause immunodeficiency, highlighting an advantage functional screens such as TREC have over genetic testing. It is likely that the subtler phenotype of idiopathic T-cell lymphopenia might be due to either polygenic interactions or alterations in regulatory regions not captured by exome sequencing. Whole genome sequencing may identify additional non-coding variants to explain the T-cell lymphopenia and help elucidate whether the findings of Xq13.1 duplications in these two boys inherited on differing $\mathrm{X}$ chromosomes is relevant to their immune findings. Complementing this technique with functional studies of the discovered genetic variants may lead to mechanistic insights that explain the T-cell lymphopenia. Such information could guide medical management; for example, if our patients have a regulatory defect leading to low IL-2 levels, replacement may promote homeostatic proliferation of lymphocytes $(13,17)$.

The goal of TREC screening is to identify patients with SCID whose lives can be saved with early bone marrow transplantation. The screen, however, is also revealing new intermediate immunodeficiency phenotypes with unknown natural history and for which clinical management is less clear. Further studying of these cases with advance genetic testing can lead to new insights in immunology that will further expand the utility of screening and improve outcomes in patients with primary immunodeficiencies.

\section{AUTHOR CONTRIBUTIONS}

XR studied cases and wrote manuscript, IC contributed with the genetic analysis and manuscript writing, JO contributed to clinical analysis and manuscript writing, $\mathrm{CH}$ contributed with identification and longitudinal assessment of patient, clinical analysis, and manuscript writing, NR contributed with clinical analysis and manuscript writing.

\section{ACKNOWLEDGMENTS}

Thanks to the Baylor College of Medicine Pediatrician-Scientist Training \& Development Program and its Associate Director Dr. Audrea Burns for help and guidance developing this report. 


\section{REFERENCES}

1. Puck JM. Neonatal screening for severe combined immunodeficiency (SCID). Curr Opin Pediatr (2011) 23(6):667-73. doi:10.1097/MOP. 0b013e32834cb9b0

2. Felgentreff K, Perez-Becker R, Speckmann C, Schwarz K, Kalwak K, Markelj G, et al. Clinical and immunological manifestations of patients with atypical severe combined immunodeficiency. Clin Immunol (2011) 141(1):73-82. doi:10.1016/j.clim.2011.05.007

3. Kwan A, Abraham RS, Currier R, Brower A, Andruszewski K, Abbott JK, et al. Newborn screening for severe combined immunodeficiency in 11 screening programs in the United States. JAMA (2014) 312(7):729-38. doi:10.1001/ jama.2014.9132

4. Avila EM, Uzel G, Hsu A, Milner JD, Turner ML, Pittaluga S, et al. Highly variable clinical phenotypes of hypomorphic RAG1 mutations. Pediatrics (2010) 126(5):e1248-52. doi:10.1542/peds.2009-3171

5. de Villartay J-P, Lim A, Al-Mousa H, Dupont S, Déchanet-Merville J, CoumauGatbois E, et al. A novel immunodeficiency associated with hypomorphic RAG1 mutations and CMV infection. J Clin Invest (2005) 115(11):3291-9. doi:10.1172/JCI25178

6. Kuijpers TW, IJspeert H, van Leeuwen EMM, Jansen MH, Hazenberg MD, Weijer KC, et al. Idiopathic CD4+ T lymphopenia without autoimmunity or granulomatous disease in the slipstream of RAG mutations. Blood (2011) 117(22):5892-6. doi:10.1182/blood-2011-01-329052

7. Arveiler B, de Saint-Basile G, Fischer A, Griscelli C, Mandel JL. Germ-line mosaicism simulates genetic heterogeneity in Wiskott-Aldrich syndrome. Am J Hum Genet (1990) 46(5):906-11.

8. Puck JM, Pepper AE, Bédard PM, Laframboise R. Female germ line mosaicism as the origin of a unique IL-2 receptor gamma-chain mutation causing X-linked severe combined immunodeficiency. J Clin Invest (1995) 95(2):895-9. doi:10.1172/JCI117740

9. O’Marcaigh AS, Puck JM, Pepper AE, Santes KD, Cowan MJ. Maternal mosaicism for a novel interleukin-2 receptor $\gamma$-chain mutation causing $\mathrm{X}$-linked severe combined immunodeficiency in a Navajo kindred. J Clin Immunol (1997) 17(1):29-33. doi:10.1023/A:1027332327827

10. Zonios DI, Falloon J, Bennett JE, Shaw PA, Chaitt D, Baseler MW, et al. Idiopathic CD4+ lymphocytopenia: natural history and prognostic factors. Blood (2008) 112(2):287-94. doi:10.1182/blood-2007-12-127878
11. Ahmad DS, Esmadi M, Steinmann WC. Idiopathic CD4 Lymphocytopenia: spectrum of opportunistic infections, malignancies, and autoimmune diseases. Avicenna JMed (2013) 3(2):37-47. doi:10.4103/2231-0770. 114121

12. Roger P-M, Bernard-Pomier G, Counillon E, Breittmayer J-P, Bernard A, Dellamonica P. Overexpression of Fas/CD95 and Fas-induced apoptosis in a patient with idiopathic CD4+ T lymphocytopenia. Clin Infect Dis (1999) 28(5):1012-6. doi:10.1086/514739

13. Scott-Algara D, Balabanian K, Chakrabarti LA, Mouthon L, Dromer F, Didier C, et al. Idiopathic CD4+ T-cell lymphocytopenia is associated with impaired membrane expression of the chemokine receptor CXCR4. Blood (2010) 115(18):3708-17. doi:10.1182/blood-2009-02-202796

14. Allenspach E, Rawlings DJ, Scharenberg AM. X-linked severe combined immunodeficiency. In: Pagon RA, Adam MP, Ardinger HH, Wallace SE, Amemiya A, Bean LJ, et al., editors. GeneReviews $\left({ }^{\circledR}\right)$ [Internet]. Seattle, WA: University of Washington (1993). Available from: http://www.ncbi.nlm.nih. gov/books/NBK1410/

15. Abraham RS, Recher M, Giliani S, Walter JE, Lee YN, Frugoni F, et al. Adultonset manifestation of idiopathic T-cell lymphopenia due to a heterozygous RAG1 mutation. J Allergy Clin Immunol (2013) 131(5):1421-3. doi:10.1016/j. jaci.2012.09.016

16. Kent WJ, Sugnet CW, Furey TS, Roskin KM, Pringle TH, Zahler AM, et al. The human genome browser at UCSC. Genome Res (2002) 12(6):996-1006. doi:10.1101/gr.229102

17. Cunningham-Rundles C, Murray HW, Smith JP. Treatment of idiopathic CD4 T lymphocytopenia with IL-2. Clin Exp Immunol (1999) 116(2):322-5. doi:10.1046/j.1365-2249.1999.00886.x

Conflict of Interest Statement: The authors declare that the research was conducted in the absence of any commercial or financial relationships that could be construed as a potential conflict of interest.

Copyright (C) 2017 Rios, Chinn, Orange, Hanson and Rider. This is an open-access article distributed under the terms of the Creative Commons Attribution License (CC BY). The use, distribution or reproduction in other forums is permitted, provided the original author(s) or licensor are credited and that the original publication in this journal is cited, in accordance with accepted academic practice. No use, distribution or reproduction is permitted which does not comply with these terms. 